\title{
Cation/anion dependence of metal ammine borohydrides/chlorides studied by ab initio calculations
}

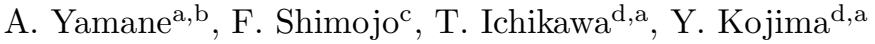 \\ ${ }^{a}$ Institute for Advanced Materials Research, Hiroshima University, Higashi-Hiroshima, \\ 739-8530, Japan \\ ${ }^{b}$ Geikisha, Inc., 4-5-44, Nishihara, Asaminami-ku, Hiroshima, 731-0113, Japan \\ ${ }^{c}$ Graduate School of Science and Technology, Kumamoto University, Kumamoto, 860-8555, \\ Japan \\ ${ }^{d}$ Graduate School of Advanced Sciences of Matter, Hiroshima University, \\ Higashi-Hiroshima, 739-8530, Japan
}

\begin{abstract}
Ammonia $\left(\mathrm{NH}_{3}\right)$, which contains about 18 mass\% of hydrogen, is regarded not only as one of the most promising hydrogen storage materials but also as an efficient carbon-free energy carrier which can be directly used by e.g. high-temperature solid oxide fuel cells. For the development of the $\mathrm{NH}_{3}$-based sustainable society, it is important to improve $\mathrm{NH}_{3}$ storage technologies. In this paper, we have studied the microscopic properties of $\mathrm{NH}_{3}$ absorption in metal borohydrides and metal chlorides by ab initio calculations. We have revealed that there is a systematic cation dependence in the $\mathrm{NH}_{3}$ absorption properties of such materials, and the properties of $\mathrm{NH}_{3}$ absorption are mainly governed by $\mathrm{NH}_{3}$-cation interactions and $\mathrm{NH}_{3}$-anion repulsions.
\end{abstract}

Keywords: ammonia storage, hydrogen storage, ab initio, microscopic property

\section{Introduction}

The development of a carbon-free sustainable society is one of the most important tasks for the human beings, and the society in which energies are generated from renewable energy sources and are stored and transferred in hydrogen $\left(\mathrm{H}_{2}\right)$ is regarded the most promising answer for this task.

Ammonia $\left(\mathrm{NH}_{3}\right)$ can be regarded as one of the most promising hydrogen storage materials since it contains about 18 mass $\%$ of hydrogen atoms and can be liquefied at about $1 \mathrm{MPa}$. We can obtain $\mathrm{H}_{2}$ molecules from $\mathrm{NH}_{3}$ by thermal decompositions or chemical reactions. For the latter, $\mathrm{H}_{2}$ molecules are easily obtained from $\mathrm{MH}-\mathrm{NH}_{3}$ system (MH: alkali metal hydride) [1, 2], and the hydrogen desorption property of this system depends on the ionicity of alkali

Email address: reuni@hiroshima-u.ac.jp (A. Yamane)

Preprint submitted to Elsevier

April 24, 2014

(C) 2014. This manuscript version is made available under the Elsevier user license http://www.elsevier.com/open-access/userlicense/1.0/ 
metals $[3,4]$. The direct use of $\mathrm{NH}_{3}$ through e.g. high-temperature solid oxide fuel cell (high-temperature SOFC) is also one of the most promising systems for the renewable energy society [5].

Though the storage and transfer of pure $\mathrm{NH}_{3}$ is easier than that of pure $\mathrm{H}_{2}$, pure $\mathrm{NH}_{3}$ is a gas state at ambient conditions and also has toxicity. So it is desired to treat $\mathrm{NH}_{3}$ more safely and more easily. We can treat $\mathrm{NH}_{3}$ more easily with low partial pressures by ammine complexes of metal chlorides $\left(\mathrm{M}_{n} \mathrm{Cl}\right)$ or borohydrides $\left(\mathrm{M}_{n} \mathrm{BH}_{4}\right)$. They can store high density of $\mathrm{NH}_{3}$ and are promising energy carriers in the hydrogen energy society $[5,6,7]$.

Magnesium chlorides $\mathrm{MgCl}_{2}$ can store high density of $\mathrm{NH}_{3}$ and the the volumetric density of $\mathrm{NH}_{3}$ in ammine complex $\mathrm{Mg}\left(\mathrm{NH}_{3}\right)_{6} \mathrm{Cl}_{2}$ is up to $93 \%$ of that of liquid ammonia [8, 9]. Sørensen et al.[7] performed density functional theory calculations on metal ammine salts and proposed that the fast $\mathrm{NH}_{3}$ absorption/desorption processes is explained by a mechanism in which individual chains of the ammines are released from the surface of the crystal.

Lithium borohydride $\left(\mathrm{LiBH}_{4}\right)$ absorbs $\mathrm{NH}_{3}$ and makes $\mathrm{Li}\left(\mathrm{NH}_{3}\right)_{m} \mathrm{BH}_{4}$ ammine complex, where $\mathrm{m}=1-4$, and can be regarded an effective $\mathrm{NH}_{3}$ storage materials $[10,11]$. Calculations on the electronic structure of $\mathrm{LiBH}_{4} \cdot \mathrm{NH}_{3}$ are performed by Ramzan et al.[12] Magnesium borohydride $\left(\mathrm{Mg}\left(\mathrm{BH}_{4}\right)_{2}\right)$ and Calcium borohydride $\left(\mathrm{Ca}\left(\mathrm{BH}_{4}\right)_{2}\right)$ also can store $\mathrm{NH}_{3}$ and have been studied as potentially promising hydrogen storage materials $[6,13]$.

For the development of the $\mathrm{NH}_{3}$-based hydrogen energy society, it is important to reveal the microscopic mechanism of $\mathrm{NH}_{3}$ absorption in these systems. The purpose of this paper is to get insights into the cation/anion dependence of the $\mathrm{NH}_{3}$ absorption properties of $\mathrm{M}_{n} \mathrm{Cl} / \mathrm{M}_{n} \mathrm{BH}_{4}$ systems by performing $a b$ initio calculations. We mainly discuss about the geometric properties of the system.

\section{Method}

We have performed $a b$ initio structure optimization calculations based on density functional theory (DFT) $[18,19,20,21,22,23,24]$. Exchange-correlation energy is treated by the generalized gradient approximation (PBE-GGA) [25] and the interaction between ions and electrons is treated by the projector augmented wave (PAW) method [26, 27], where we consider $1 s, 2 s$, and $2 s 2 p$ electrons of $\mathrm{H}, \mathrm{Li}$, and $\mathrm{N}$ atoms, respectively, as valence electrons. The plane wave expansion is performed by $\Gamma$ point. The cut-off energy of the plane waves is $476 \mathrm{eV}$ and that of the pseudocharge density is $2040 \mathrm{eV}$. The structure optimization calculation is performed by the projected velocity verlet method [28] and we regard that the system becomes to be stable when the energy change is within the calculation error during a few hundred steps. The time step for the structure optimizations is about $1 \mathrm{fs}(40$ a.u. $\simeq 0.968 \mathrm{fs})$.

The calculation cell is a cubic cell with the edge length of $16.0 \AA$. We put one $\mathrm{M}_{n} \mathrm{X}_{2}$ cluster and one or two $\mathrm{NH}_{3}$ molecules in the cell, where $\mathrm{M}_{n} \mathrm{X}_{2}$ indicates $\mathrm{Li}_{2} \mathrm{Cl}_{2}, \mathrm{Na}_{2} \mathrm{Cl}_{2}, \mathrm{~K}_{2} \mathrm{Cl}_{2}, \mathrm{Mg}_{1} \mathrm{Cl}_{2}, \mathrm{Ca}_{1} \mathrm{Cl}_{2}, \mathrm{Li}_{2}\left(\mathrm{BH}_{4}\right)_{2}, \mathrm{Na}_{2}\left(\mathrm{BH}_{4}\right)_{2}, \mathrm{~K}_{2}\left(\mathrm{BH}_{4}\right)_{2}$, 
(a)

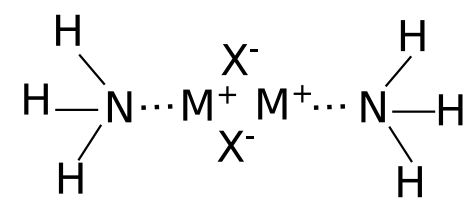

(b)

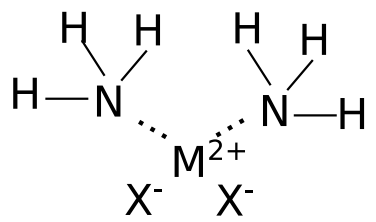

Figure 1: Schematic illustrations of the system for (a) $M_{2} X_{2}+2 N_{3}$, where $M$ is the group 1 elements, and (b) $\mathrm{MX}_{2}+2 \mathrm{NH}_{3}$, where $\mathrm{M}$ is the group 2 elements.

Table 1: Absorption energy of $\mathrm{NH}_{3}$ to $\mathrm{M}_{n} \mathrm{X}_{2}$ calculated from the difference of the total energy of $\mathrm{M}_{n} \mathrm{X}_{2}+m \mathrm{NH}_{3}$ system and the sum of the energies of isolated $\mathrm{M}_{n} \mathrm{X}_{2}$ and $\mathrm{NH}_{3}$. The values for $2 \mathrm{NH}_{2}$ is the value averaged over two $\mathrm{NH}_{3}$ molecules. The unit in $\mathrm{eV}$.

\begin{tabular}{l|c|c}
\hline & $1 \mathrm{NH}_{3}$ & $2 \mathrm{NH}_{3}$ \\
\hline $\mathrm{Li}_{2} \mathrm{Cl}_{2}$ & 0.80 & 0.77 \\
$\mathrm{Na}_{2} \mathrm{Cl}_{2}$ & 0.66 & 0.61 \\
$\mathrm{~K}_{2} \mathrm{Cl}_{2}$ & 0.52 & 0.53 \\
$\mathrm{Mg}_{1} \mathrm{Cl}_{2}$ & 1.23 & 1.12 \\
$\mathrm{Ca}_{1} \mathrm{Cl}_{2}$ & 1.06 & 0.99 \\
\hline $\mathrm{Li}_{2}\left(\mathrm{BH}_{4}\right)_{2}$ & 0.80 & 0.74 \\
$\mathrm{Na}_{2}\left(\mathrm{BH}_{4}\right)_{2}$ & 0.67 & 0.63 \\
$\mathrm{~K}_{2}\left(\mathrm{BH}_{4}\right)_{2}$ & 0.54 & 0.52 \\
$\mathrm{Mg}_{1}\left(\mathrm{BH}_{4}\right)_{2}$ & 1.01 & 0.93 \\
$\mathrm{Ca}_{1}\left(\mathrm{BH}_{4}\right)_{2}$ & 0.94 & 0.88 \\
\hline
\end{tabular}

$\left.\mathrm{Mg}\left(\mathrm{BH}_{4}\right)_{2}, \mathrm{Ca}\left(\mathrm{BH}_{4}\right)_{2}\right)$. These clusters correspond to a model of a disordered surface of the crystalline solid. Figure 1 is the schematic illustrations of the system in our calculations.

We have also performed molecular dynamics (MD) simulations to see the stability of the system. The MD simulations are performed under the canonical ensemble (constant-temperature constant-cellsize condition). The temperature is controled to be $300 \mathrm{~K}$ with Nosé thermostat [30]. We have performed MD simulations up to 2000 steps (about $2 \mathrm{ps}$ ) and during the simulations $\mathrm{NH}_{3}$ stays on $\mathrm{M}$ in $\mathrm{M}_{n} \mathrm{X}_{2}$ cluster.

\section{Results and Discussions}

For each systems, $\mathrm{NH}_{3}$ molecules absorb on metal (cation) atoms directing its $\mathrm{N}$ atom to metal atom. The cartesian coordinates of the stabilized systems are in supplementary material.

In table 1 we show the cation/anion dependence of the absorption energy of $\mathrm{NH}_{3}$ to $\mathrm{M}_{n} \mathrm{X}_{2}$. These energies are calculated from the difference between the 
Table 2: Interatomic distances between metal atom and $\mathrm{N}$ in $\mathrm{NH}_{3}$. The unit is in $\AA$.

\begin{tabular}{l|c|cc}
\hline & $1 \mathrm{NH}_{3}$ & \multicolumn{2}{|c}{$2 \mathrm{NH}_{3}$} \\
\hline $\mathrm{Li}_{2} \mathrm{Cl}_{2}$ & 2.08 & 2.09 & 2.09 \\
$\mathrm{Na}_{2} \mathrm{Cl}_{2}$ & 2.40 & 2.41 & 2.41 \\
$\mathrm{~K}_{2} \mathrm{Cl}_{2}$ & 2.87 & 2.88 & 2.87 \\
$\mathrm{Mg}_{1} \mathrm{Cl}_{2}$ & 2.16 & 2.18 & 2.18 \\
$\mathrm{Ca}_{1} \mathrm{Cl}_{2}$ & 2.53 & 2.54 & 2.54 \\
\hline $\mathrm{Li}_{2}\left(\mathrm{BH}_{4}\right)_{2}$ & 2.08 & 2.10 & 2.09 \\
$\mathrm{Na}_{2}\left(\mathrm{BH}_{4}\right)_{2}$ & 2.42 & 2.40 & 2.40 \\
$\mathrm{~K}_{2}\left(\mathrm{BH}_{4}\right)_{2}$ & 2.85 & 2.85 & 2.86 \\
$\mathrm{Mg}_{1}\left(\mathrm{BH}_{4}\right)_{2}$ & 2.16 & 2.20 & 2.20 \\
$\mathrm{Ca}_{1}\left(\mathrm{BH}_{4}\right)_{2}$ & 2.54 & 2.56 & 2.55 \\
\hline
\end{tabular}

total energy of $\mathrm{M}_{n} \mathrm{X}_{2}+m \mathrm{NH}_{3}$ system and the sum of the energies of isolated $\mathrm{M}_{n} \mathrm{X}_{2}$ and $\mathrm{NH}_{3}$.

This table shows that the $\mathrm{NH}_{3}$ absorption energy decreases in order of $\mathrm{Li}>$ $\mathrm{Na}>\mathrm{K}$, and $\mathrm{Mg}>\mathrm{Ca}$. The $\mathrm{NH}_{3}$ absorption energy of group 2 elements $\left(\mathrm{MgX}_{2}\right.$, $\left.\mathrm{CaX}_{2}\right)$ has higher (stronger) values than that of group 1 elements $\left(\mathrm{Li}_{2} \mathrm{X}_{2}, \mathrm{Na}_{2} \mathrm{X}_{2}\right.$, $\mathrm{K}_{2} \mathrm{X}_{2}$ ). We can also see that the $\mathrm{NH}_{3}$ absorption energies of metal chlorides are clearly larger than that of metal borohydrides for group 2 elements. On the other hand, the $\mathrm{NH}_{3}$ absorption energies of metal chlorides and metal borohydrides take almost same values if the metal atoms are the same group 1 element, i.e., the dependence of $\mathrm{NH}_{3}$ absorption energies on anions is small for group 1 elements. The absorption energies of first $\mathrm{NH}_{3}$ and second $\mathrm{NH}_{3}$ also take similar values, though the energy slightly decreases when the number of absorbed $\mathrm{NH}_{3}$ becomes 1 to 2 .

Table 2 shows the cation/anion dependence of the interatomic distance between the metal atom and the $\mathrm{N}$ atom in $\mathrm{NH}_{3}$. There is clear cation dependence in the metal-N distance, i.e., metal-N distance increases in order of $\mathrm{Li}<\mathrm{Na}<$ $\mathrm{K}$, and $\mathrm{Mg}<\mathrm{Ca}$. On the other hand, there is only small anion dependence in the metal- $\mathrm{N}$ distance. These results indicates that the metal- $\mathrm{N}$ interactions are mainly governed by cations, and the effect of anions on metal-N interactions is small.

Table 3 shows the metal-anion distances, where we take the position of anion as the position of $\mathrm{Cl}$ atom or $\mathrm{B}$ atom in $\mathrm{BH}_{4}$. That is, this table shows metal$\mathrm{Cl}$ distances for metal chlorides and metal-B distances for metal borohydrides. These results also shows clear cation dependence in metal-anion distance. The $\mathrm{M}$-anion distance increases in order of $\mathrm{Li}<\mathrm{Na}<\mathrm{K}$, and $\mathrm{Mg}<\mathrm{Ca}$. and the anion dependence is relatively small. However, in contrast to M-N distance, there is small but not negligible anion dependence in metal-anion distance, i.e., metal-Cl distance is slightly shorter than metal-B distance for $\mathrm{Li}_{2} \mathrm{X}_{2}$, and longer for $\mathrm{MgX}_{2}$ and $\mathrm{CaX}_{2}$. For $\mathrm{Na}_{2} \mathrm{X}_{2}$ and $\mathrm{K}_{2} \mathrm{X}_{2}$, it is not clear which metal-anion distance is longer than the other. 
Table 3: Metal-Cl distances (for metal chlorides) and metal-B distances (for metal borohydrides). The unit is in $\AA$.

\begin{tabular}{l|cccc|cccc}
\hline & \multicolumn{4}{|c|}{$1 \mathrm{NH}_{3}$} & \multicolumn{4}{c}{$2 \mathrm{NH}_{3}$} \\
\hline $\mathrm{Li}_{2} \mathrm{Cl}_{2}$ & 2.22 & 2.22 & 2.30 & 2.32 & 2.30 & 2.28 & 2.30 & 2.28 \\
$\mathrm{Na}_{2} \mathrm{Cl}_{2}$ & 2.52 & 2.53 & 2.58 & 2.67 & 2.56 & 2.66 & 2.56 & 2.65 \\
$\mathrm{~K}_{2} \mathrm{Cl}_{2}$ & 2.93 & 2.91 & 3.04 & 2.96 & 3.04 & 2.94 & 3.04 & 2.95 \\
$\mathrm{Mg}_{1} \mathrm{Cl}_{2}$ & \multicolumn{2}{|c}{2.23} & 2.23 & 2.28 & 2.28 \\
$\mathrm{Ca}_{1} \mathrm{Cl}_{2}$ & 2.54 & 2.53 & 2.58 & 2.58 \\
\hline $\mathrm{Li}_{2}\left(\mathrm{BH}_{4}\right)_{2}$ & 2.26 & 2.19 & 2.38 & 2.40 & 2.37 & 2.33 & 2.32 & 2.37 \\
$\mathrm{Na}_{2}\left(\mathrm{BH}_{4}\right)_{2}$ & 2.61 & 2.47 & 2.55 & 2.70 & 2.51 & 2.74 & 2.74 & 2.51 \\
$\mathrm{~K}_{2}\left(\mathrm{BH}_{4}\right)_{2}$ & 2.89 & 2.90 & 3.17 & 2.93 & 2.90 & 3.11 & 2.91 & 3.12 \\
$\mathrm{Mg}_{1}\left(\mathrm{BH}_{4}\right)_{2}$ & 2.15 & 2.26 & 2.23 & 2.24 \\
$\mathrm{Ca}_{1}\left(\mathrm{BH}_{4}\right)_{2}$ & 2.49 & 2.49 & 2.52 & 2.52 \\
\hline \multicolumn{10}{c}{}
\end{tabular}

Table 4: Nearest $\mathrm{H}_{\mathrm{inNH} 3}-\mathrm{Cl}$ distances (for metal chlorides) and nearest $\mathrm{H}_{\mathrm{inNH} 3}-\mathrm{H}_{\mathrm{inBH} 4}$ distances (for metal borohydrides). The unit is $\AA$.

\begin{tabular}{l|c|cc}
\hline & $1 \mathrm{NH}_{3}$ & \multicolumn{2}{|c}{$2 \mathrm{NH}_{3}$} \\
\hline $\mathrm{Li}_{2} \mathrm{Cl}_{2}$ & 3.41 & 3.28 & 3.63 \\
$\mathrm{Na}_{2} \mathrm{Cl}_{2}$ & 2.57 & 2.53 & 2.58 \\
$\mathrm{~K}_{2} \mathrm{Cl}_{2}$ & 2.40 & 2.45 & 2.45 \\
$\mathrm{Mg}_{1} \mathrm{Cl}_{2}$ & 3.28 & 3.18 & 3.10 \\
$\mathrm{Ca}_{1} \mathrm{Cl}_{2}$ & 3.03 & 2.70 & 2.74 \\
\hline $\mathrm{Li}_{2}\left(\mathrm{BH}_{4}\right)_{2}$ & 3.02 & 2.96 & 2.89 \\
$\mathrm{Na}_{2}\left(\mathrm{BH}_{4}\right)_{2}$ & 3.48 & 2.02 & 2.03 \\
$\mathrm{~K}_{2}\left(\mathrm{BH}_{4}\right)_{2}$ & 1.95 & 1.91 & 1.87 \\
$\mathrm{Mg}_{1}\left(\mathrm{BH}_{4}\right)_{2}$ & 2.38 & 2.61 & 2.63 \\
$\mathrm{Ca}_{1}\left(\mathrm{BH}_{4}\right)_{2}$ & 2.93 & 2.87 & 2.96 \\
\hline
\end{tabular}


Table 5: Nearest (left) and farthest (right) N-H distances in $\mathrm{NH}_{3}$. The unit is $\AA$.

\begin{tabular}{l|ll|ll}
\hline & \multicolumn{2}{|c|}{$1 \mathrm{NH}_{3}$} & \multicolumn{2}{c}{$2 \mathrm{NH}_{3}$} \\
\hline $\mathrm{Li}_{2} \mathrm{Cl}_{2}$ & 1.037 & 1.039 & 1.037 & 1.039 \\
$\mathrm{Na}_{2} \mathrm{Cl}_{2}$ & 1.037 & 1.045 & 1.037 & 1.046 \\
$\mathrm{~K}_{2} \mathrm{Cl}_{2}$ & 1.037 & 1.049 & 1.037 & 1.048 \\
$\mathrm{Mg}_{1} \mathrm{Cl}_{2}$ & 1.039 & 1.039 & 1.037 & 1.039 \\
$\mathrm{Ca}_{1} \mathrm{Cl}_{2}$ & 1.038 & 1.041 & 1.037 & 1.044 \\
\hline $\mathrm{Li}_{2}\left(\mathrm{BH}_{4}\right)_{2}$ & 1.037 & 1.039 & 1.037 & 1.039 \\
$\mathrm{Na}_{2}\left(\mathrm{BH}_{4}\right)_{2}$ & 1.038 & 1.038 & 1.037 & 1.046 \\
$\mathrm{~K}_{2}\left(\mathrm{BH}_{4}\right)_{2}$ & 1.037 & 1.047 & 1.037 & 1.048 \\
$\mathrm{Mg}_{1}\left(\mathrm{BH}_{4}\right)_{2}$ & 1.038 & 1.039 & 1.037 & 1.039 \\
$\mathrm{Ca}_{1}\left(\mathrm{BH}_{4}\right)_{2}$ & 1.038 & 1.039 & 1.037 & 1.038 \\
\hline
\end{tabular}

Table 4 shows nearest $\mathrm{H}_{\mathrm{inNH} 3}-\mathrm{Cl}$ distances (for metal chlorides) and nearest $\mathrm{H}_{\text {inNH3 }}-\mathrm{H}_{\mathrm{inBH} 4}$ distances (for metal borohydrides). For the systems with two $\mathrm{NH}_{3}$, the distances take small value when the metals are $\mathrm{Na}$ or $\mathrm{K}$, though the $\mathrm{H}_{\text {inNH3 }}-\mathrm{H}_{\mathrm{inBH} 4}$ distance for $\mathrm{Na}_{2}\left(\mathrm{BH}_{4}\right)_{2}$ and one $\mathrm{NH}_{3}$ system is not small. For the other metal cations, on the other hand, the $\mathrm{H}$ atom is not close to the anions compared with that for $\mathrm{Na}_{2} \mathrm{X}_{2}$ or $\mathrm{K}_{2} \mathrm{X}_{2}$.

It indicates that metal atom and $\mathrm{N}$ atom strongly interacts for $\mathrm{Li}_{2} \mathrm{X}_{2}, \mathrm{MgX} \mathrm{X}_{2}$ and $\mathrm{CaX}_{2}$, and coulomb interactions between $\mathrm{H}^{\delta+}$ in $\mathrm{NH}_{3}$ and $\mathrm{Cl}^{-} / \mathrm{BH}_{4}^{-}$has relatively small effects on the atomic configurations.

The results of our calculations show that, although the $\mathrm{NH}_{3}$ absorptions on metal chlorides/borohydrides are mainly governed by the metal- $\mathrm{N}$ interaction, anion has almost no effect on the metal- $\mathrm{NH}_{3}$ interactions. It means that the anion dependence of these systems are directly governed by anion- $\mathrm{NH}_{3}$ interactions and anion-metal interactions, and we can see almost no indirect effects of anion on metal-N distance.

This means that the anion dependence of the system mainly come from anion- $\mathrm{NH}_{3}$ repulsion. For $\mathrm{MgX}_{2}$ and $\mathrm{CaX}_{2}$, in which we can see clear anion dependence in the absorption energy, anion-metal-anion cluster takes bent form. Since the isolated $\mathrm{MX}_{2}$ takes one-dimensional form, the bent structure of these cluster with $\mathrm{NH}_{3}$ comes from the repulsion between anions and $\mathrm{NH}_{3}$.

In table 5 we show the cation/anion dependence of the nearest $\mathrm{N}-\mathrm{H}$ distance and farthest $\mathrm{N}-\mathrm{H}$ distance in $\mathrm{NH}_{3}$. While the nearest $\mathrm{N}-\mathrm{H}$ distance takes almost same values, the farthest $\mathrm{N}-\mathrm{H}$ distance depends on the cations. The farthest $\mathrm{N}-\mathrm{H}$ distance takes large value when the system is $\mathrm{Na}_{2} \mathrm{X}_{2}$ or $\mathrm{K}_{2} \mathrm{X}_{2}$, except the system $\mathrm{Na}_{2}\left(\mathrm{BH}_{4}\right)_{2}$ with one $\mathrm{NH}_{3}$.

As we have seen in table $4, \mathrm{H}^{\delta+}$ in $\mathrm{NH}_{3}$ and $\mathrm{Cl}^{-}$or $\mathrm{H}^{\delta-}$ in $\mathrm{BH}_{4}$ come close to each other for $\mathrm{Na}_{2} \mathrm{X}_{2}$ and $\mathrm{K}_{2} \mathrm{X}_{2}$.

However, though the $\mathrm{H}-\mathrm{H}$ or $\mathrm{H}-\mathrm{Cl}$ distance is small for $\mathrm{Na}_{2} \mathrm{X}_{2}$ or $\mathrm{K}_{2} \mathrm{X}_{2}$, there is almost no anion dependence in the absorption energy for group 1 elements. These results show that the effect of $\mathrm{H}^{\delta+}-\mathrm{H}^{\delta-}$ and $\mathrm{H}^{\delta+}-\mathrm{Cl}^{-}$coulombic 
attractions is small compared with $\mathrm{M}-\mathrm{N}$ interactions, and the anion dependence of the system comes from the interation between whole- $\mathrm{NH}_{3}$ and whole- $\mathrm{BH}_{4}$ or $\mathrm{Cl}$, not from the specific interaction between $\mathrm{H}^{\delta+}$ in $\mathrm{NH}_{3}$ and $\mathrm{H}^{\delta-}$ in $\mathrm{BH}_{4}$ or $\mathrm{Cl}^{-}$.

\section{Summary}

We have performed ab initio calculations on the $\mathrm{NH}_{3}$ absorption on $\mathrm{Li}_{2} \mathrm{Cl}_{2}$, $\mathrm{Na}_{2} \mathrm{Cl}_{2}, \mathrm{~K}_{2} \mathrm{Cl}_{2}, \mathrm{MgCl}_{2}, \mathrm{CaCl}_{2}, \mathrm{Li}_{2}\left(\mathrm{BH}_{4}\right)_{2}, \mathrm{Na}_{2}\left(\mathrm{BH}_{4}\right)_{2}, \mathrm{~K}_{2}\left(\mathrm{BH}_{4}\right)_{2}, \mathrm{Mg}\left(\mathrm{BH}_{4}\right)_{2}$ and $\mathrm{Ca}\left(\mathrm{BH}_{4}\right)_{2}$ clusters.

$\mathrm{NH}_{3}$ absorbs on $\mathrm{M}_{n} \mathrm{X}_{2}$ directing its $\mathrm{N}$ atom to metal (cation) atom, and absorptions energy of $\mathrm{NH}_{3}$ mainly depends on metal atoms and also depends on anions.

The absorption energy of $\mathrm{NH}_{3}$ has relatively strong anion dependence for group 2 elements $\left(\mathrm{MgX}_{2}\right.$ and $\left.\mathrm{CaX}_{2}\right)$, though the coulombic interaction between anion and $\mathrm{NH}_{3}$ seems stronger for $\mathrm{Na}_{2} \mathrm{X}_{2}$ and $\mathrm{K}_{2} \mathrm{X}_{2}$. On the other hand, the structure of $\mathrm{MX}_{2}$, where $\mathrm{M}$ is group 2 element, are bent by $\mathrm{NH}_{3}$ absorption. From these results we can say that the anion dependence mainly comes from $\mathrm{NH}_{3}$-anion repulsive interactions.

\section{Acknowledgement}

This study was supported in part by Energy Carrier Project of JST ALCA (Japan Science and Technology Agency - Advanced Low Carbon Technology Research and Development Program).

\section{References}

[1] T. Ichikawa, N. Hanada, S. Isobe, H. Y. Leng, and H. Fujii, Mechanism of Novel Reaction from $\mathrm{LiNH}_{2}$ and $\mathrm{LiH}$ to $\mathrm{Li}_{2} \mathrm{NH}$ and $\mathrm{H}_{2}$ as a Promising Hydrogen Storage System, J. Phys. Chem. B 108 (2004) 7887-7892

[2] Y. Kojima, K. Tange, S. Hino, S. Isobe, M. Tsubota, K. Nakamura, M. Nakatake, H. Miyaoka, H. Yamamoto, and T. Ichikawa, Molecular hydrogen carrier with activated nanohydride and ammonia, J. Mater. Res. 24 (2009) $2185-2190$

[3] H. Yamamoto, H. Miyaoka, S. Hino, H. Nakanishi, T. Ichikawa, and Y. Kojima, Recyclable hydrogen storage system composed of ammonia and alkali metal hydride, Int. J. Hydrogen Energy 34 (2009) 9760-9764

[4] A. Yamane, F. Shimojo, K. Hoshino, T. Ichikawa, and K. Kojima, Ab initio study on the hydrogen desorption from $\mathrm{MHNH}_{3}(\mathrm{M}=\mathrm{Li}, \mathrm{Na}, \mathrm{K})$ hydrogen storage systems, J. Chem Phys. 134 (2011) 124515 
[5] A. Klerke, C. H. Christensen, J. K. Nørskov, and T. Vegge, Ammonia for hydrogen storage: challenges and opportunities, J. Mater. Chem. 18 (2008) 2304-2310

[6] G. Soloveichik, J.-H. Her, P. W. Stephens, Y. Gao, J. Rijssenbeek, M. Andrus, and J.-C. Zhao, Ammine Magnesium Borohydride Complex as a New Material for Hydrogen Storage: Structure and Properties of $\mathrm{Mg}\left(\mathrm{BH}_{4}\right)_{2} 2 \mathrm{NH}_{3}$, Inorg. Chem. 47 (2008) 4290-4298

[7] R. Z. Sørensen, J. S. Hummelshøj, A. Klerke, J. B. Reves, T. Vegge, J. K. Nørskov, and C. H. Christensen, Indirect, reversible high-density hydrogen storage in compact metal ammine salts, J. Am. Chem. Soc. 130 (2008) $8660-8668$

[8] T. D. Elmøe, R. Z. Sørensen, U. Quaade, C. H. Christensen, J. K. Nørskov, and T. Johannessen, A high-density ammonia storage/delivery system based on $\mathrm{Mg}\left(\mathrm{NH}_{3}\right)_{6} \mathrm{Cl}_{2}$ for $S C R D e N O_{x}$ in vehicles, Chem. Eng. Sci. 61 (2006) 2618-2625

[9] J. S. Hummelshøj, R. Z. Sørensen, M. Y. Kustova, T. Johannessen, J. K. Nørskov, and C. H. Christensen, Generation of Nanopores during Desorption of $\mathrm{NH}_{3}$ from $\mathrm{Mg}\left(\mathrm{NH}_{3}\right)_{6} \mathrm{Cl}_{2}$, J. Am. Chem. Soc. 128 (2006) 16-17

[10] S. R. Johnson, W. I. F. David, D. M. Royse, M. Sommariva, C. Y. Tang, F. P. A. Fabbiani, M. O. Jones, and P. P. Edwards, The Monoammoniate of Lithium Borohydride, $\mathrm{Li}\left(\mathrm{NH}_{3}\right) \mathrm{BH}_{4}$ : An Effective Ammonia Storage Compound, Chem. Asian J. 4 (2009) 849-854

[11] X. Zheng, G. Wu, W. Li, Z. Xiong, T. He, J. Guo, H. Chen, and P. Chen, Releasing $17.8 \mathrm{wt} \% \mathrm{H}_{2}$ from lithium borohydride ammoniate, Energy Environ. Sci. 4 (2011) 3593-3600

[12] M. Ramzan, F. Silvearv, S. Lebègue, and R. Ahuja, Electronic Structure from First-Principles of $\mathrm{LiBH}_{4} \mathrm{NH}_{3}, \mathrm{Sr}\left(\mathrm{NH}_{2} \mathrm{BH}_{3}\right)_{2}$, and $\mathrm{Li}_{2} \mathrm{Al}\left(\mathrm{BH}_{4}\right)_{5} 6 \mathrm{NH}_{3}$ for Hydrogen Storage Applications, J. Phys. Chem. C 115 (2011) 2003620042

[13] H. Chu, G. Wu, Z. Xiong, J. Guo, T. He, and P. Chen, Structure and Hydrogen Storage Properties of Calcium Borohydride Diammoniate, Chem. Mater. 22 (2010) 6021-6028

[14] S. Hino, N. Ogita, M. Udagawa, T. Ichikawa and Y. Kojima, Thermodynamic properties of lithium amide under hydrogen pressure determined by Raman spectroscopy , J. Appl. Phys. 105 (2009) 023527

[15] T. Kar, S. Scheiner and L. Li, Theoretical investigation on the mechanism of $\mathrm{LiH}+\mathrm{NH}_{3} \quad \mathrm{LiNH}_{2}+\mathrm{H}_{2}$ reaction, J. Mol. Struct.: THEOCHEM 857 (2008) 111-114 
[16] D. Y. Kim, N. J. Singh, H. M. Lee, and K. S. Kim, Hydrogen-Release Mechanisms in Lithium Amidoboranes, Chem. Eur. J. 15 (2009) 5598-5604

[17] A. Yamane, F. Shimojo, K. Hoshino, T. Ichikawa and Y. Kojima, $\mathrm{H}_{2}$ desorption from $\mathrm{LiH}$ cluster and $\mathrm{NH}_{3}$ molecule studied by ab initio molecular dynamics simulation, J. Mol. Struct.: THEOCHEM 944 (2010) 137-145

[18] P. Hohenberg and W. Kohn, Inhomogeneous Electron Gas, Phys. Rev. 136 (1964) B864-B871

[19] W. Kohn and L. J. Sham, Self-Consistent Equations Including Exchange and Correlation Effects, Phys. Rev. 140 (1965) A1133-A1138

[20] M. P. Teter, M. C. Payne and D. C. Allan, Solution of Schrödingers equation for large systems, Phys. Rev. B 40 (1989) 12255-12263

[21] T. A. Arias, M. C. Payne and J. D. Joannopoulos, Ab initio moleculardynamics techniques extended to large-length-scale systems, Phys. Rev. B 45 (1992) 1538-1549

[22] T. A. Arias, M. C. Payne and J. D. Joannopoulos, Ab initio molecular dynamics: Analytically continued energy functionals and insights into iterative solutions, Phys. Rev. Lett. 69 (1992) 1077-1080

[23] G. Kresse and J. Hafner, Ab initio molecular-dynamics simulation of the liquid-metalamorphous-semiconductor transition in germanium, Phys. Rev. B 49 (1994) 14251-14269

[24] F. Shimojo, Y. Zempo, K. Hoshino and M. Watabe, First-principles molecular-dynamics simulation of expanded liquid rubidium, Phys. Rev. B 52 (1995) 9320-9329

[25] J. P. Perdew, K. Burke and M. Ernzerhof, Generalized Gradient Approximation Made Simple, Phys. Rev. Lett. 77 (1996) 3865-3868

[26] P. E. Blöchl, Projector augmented-wave method, Phys. Rev. B 50 (1994) 17953-17979

[27] G. Kresse and D. Joubert, From ultrasoft pseudopotentials to the projector augmented-wave method, Phys. Rev. B 59 (1999) 1758-1775

[28] H. Jonsson, G. Mills, and K. W. Jacobsen, Nudged elastic band method for finding minimum energy paths of transitions, in: B. J. Berne, G. Ciccotti, and D. F. Coker (Eds.), Classical and Quantum Dynamics in Condensed Phase Simulations, World Scientific, Singapore, 1998, pp. 385.

[29] R. S. Mulliken, Electronic Population Analysis on LCAOMO Molecular Wave Functions. I, J. Chem. Phys. 23 (1955) 1833-1840

[30] S. Nosé, A unified formulation of the constant temperature molecular dynamics methods, J. Chem. Phys. 81 (1984) 511-519 
*Graphical Abstract

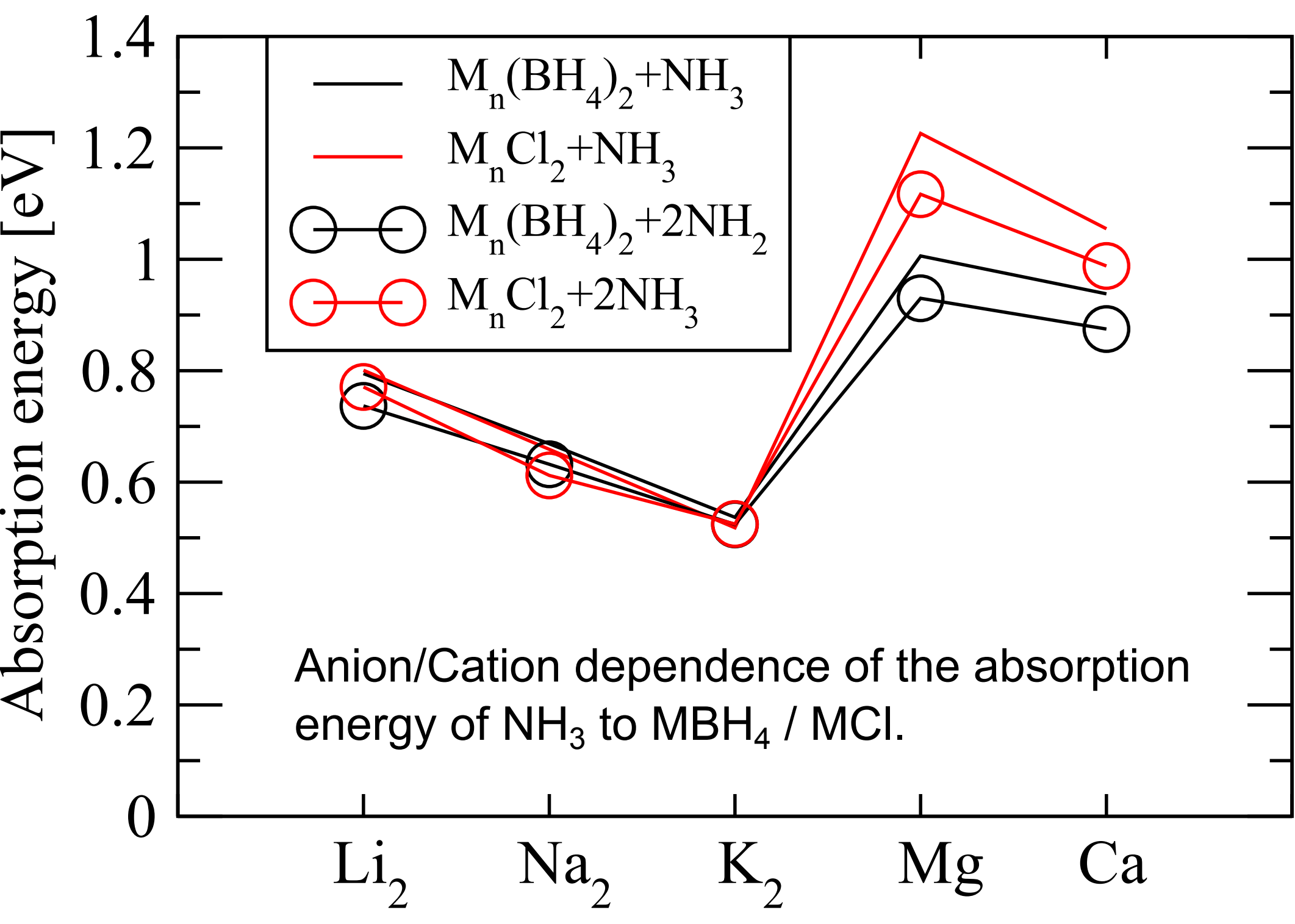

